\title{
PENGARUH PENDIDIKAN KESEHATAN TENTANG INFEKSI SALURAN NAPAS AKUT (ISPA) TERHADAP PENGETAHUAN KELUARGA DI RUANG IGD RSUD JAYAPURA
}

\author{
Juliana Hursepuny ${ }^{1}$, Rifki Sakinah Nompo ${ }^{2}$, Arvia $^{3}$ \\ 1) Rumah Sakit Umum Derah Jayapura \\ ${ }^{2)}$ Prodi Pendidikan Profesi Ners STIKES Jayapura \\ ${ }^{3)}$ Prodi S1 Keperawatan STIKES Jayapura \\ email: rifkisakinahnompo@gmail.com
}

\begin{abstract}
ABSTRAK
Latar Belakang: Infeksi Saluran Napas Akut (ISPA) merupakan penyakit pada saluran pernapasan bagian atas dan bawah, terjadi pada saluran pernapasan dimulai dari hidung, telinga tengah, faring (tenggorokan), kotak suara (laring), bronchi, bronkhioli dan paru. Jenis penyakit infeksi saluran pernapasan bagian atas yaitu batuk, pilek, sakit telinga (otitis media) dan radang tenggorokan (faringitis), sedangkan jenis penyakit yang termasuk infeksi saluran pernapasan bagian bawah yaitu bronchitis, bronkhiolitis dan pneumonia. ISPA berada pada daftar 10 penyakit terbanyak di rumah sakit, episode penyakit batuk dan pilek terjadi 3-6 kali pertahun terutama balita dan anak-anak. Metode Penelitian: Menggunakan Quasi Eksperimen One Group Pre Test-Post Test tanpa kelompok kontrol. Waktu penelitian dilakukan pada bulan Agustus Oktober 2019. Peneliti menggunakan minimal sampling 30 responden. Menggunakan Wilcoxon Test untuk melihat pengaruh pendidikan kesehatan sebelum dan setelah terhadap pengetahuan keluarga tentang ISPA. Hasil: Diketahui tingkat pengetahuan keluarga sebelum diberikan pendidikan kesehatan tentang ISPA dengan kriteria baik 15 orang $(50.0 \%)$, cukup 6 orang $(20.0 \%)$, dan kurang 9 orang $(30.0 \%)$. Tingkat pengetahuan keluarga setelah diberikan pendidikan kesehatan tentang ISPA dengan kriteria baik 30 orang $(100.0 \%)$. Hasil uji Wilcoxon $\rho$ (Asymp. Sig. 2-tailed) $=0.000<0.05$. Kesimpulan \& Saran: Hasil penelitian diketahui ada pengaruh pendidikan kesehatan tentang infeksi saluran napas akut (ISPA) terhadap pengetahuan keluarga di Ruang IGD RSUD Jayapura. Diharapkan perawat dapat lebih mengembangkan diri sebagai educator dengan mengikuti pelatihan-pelatihan yang dapat meningkatkan rasa percaya dan keilmuan sebagai perawat dalam menyebarkan informasi dan memberikan sosialisasi khususnya tentang ISPA.
\end{abstract}

Kata Kunci: Pendidikan Kesehatan, Pengetahuan Keluarga, ISPA

\begin{abstract}
Background: Acute Respiratory Infections (ARIs) is a disease of the upper and lower respiratory tract, occurring in the respiratory tract starting from the nose, middle ear, pharynx (throat), voice box (larynx), bronchi, bronchi and lungs. Types of upper respiratory tract infections are cough, flu, earache (otitis media) and inflammation of the throat (pharyngitis), while the types of diseases that include lower respiratory tract infections are bronchitis, bronchhiolitis and pneumonia. ARIs is on the list of 10 most diseases in the hospital, cough and cold episodes come to pass 3-6 times per year, especially toddlers and children. Research Method: Using Quasi Experiment One Group Pre-Post-Test without control group. The study was conducted in August - October 2019. Researchers used a minimum sampling of 30 respondents. Use the Wilcoxon Test to see the effect of pre and post health education about ARIs toward family knowledge. Results: The level of knowledge about ARIs toword family before being given health education with good criteria 15 people (50.0\%), enough 6 people (20.0\%), and less 9 people (30.0\%), after being given health education increase with good criteria 30 people (100.0\%), and wilcoxon test results $\rho$ (Asymp. Sig. 2tailed)

$=0,000<0.05$. Conclusions \& Suggestions: There is an influence of health education about acute respiratory infections (ARIs) toward family knowledge in the Emergency Room at Jayapura General Hospital. research expected nurses in thefurther can develop themselves as educators by attending trainings that can increase confidence and knowledge as nurses in disseminating information and providing socialization in particular about ARIs.
\end{abstract}

Keywords: Health education, Family Knowledge, URIs 


\section{PENDAHULUAN}

Infeksi Saluran Napas Akut (ISPA) merupakan penyakit pada saluran pernapasan bagian atas dan bawah, penyakit ini sering diderita oleh bayi, anakanak, orang usia lanjut dan atau orang yang memiliki masalah kesehatan (Dinas Kesehatan Malang, 2015). ISPA terjadi pada saluran pernapasan dimulai dari hidung, telinga tengah, faring (tenggorokan), kotak suara (laring), bronchi, bronkhioli dan paru. Jenis penyakit infeksi saluran pernapasan bagian atas yaitu batuk, pilek, sakit telinga (otitis media) dan radang tenggorokan (faringitis), sedangkan jenis penyakit yang termasuk infeksi saluran pernapasan bagian bawah yaitu bronchitis, bronkhiolitis dan pneumonia (POM, 2011).

Menurut Kemenkes RI 2018 prevalensi ISPA di Indonesia pada rentang tahun 2013-2018 terjadi penurunan jumlah kasus dari $25.0 \%$ menjadi $9.3 \%$ per 300.000 jiwa. ISPA menyebabkan kematian bayi dan balita yang cukup tinggi berkisar antara 1 dari 4 kematian yang terjadi, setiap anak diperkirakan mengalami 3-6 episode ISPA setiap tahunnya. Tercatat data dari Depkes tahun 2008 terdapat 40\%60\% kunjungan di Puskesmas memiliki kasus ISPA.

Di dunia saat ini telah menjalani program Milenium Development Goals (MDGs) dari tahun 2000-2015 dimana terdapat 2/3 kasus kematian tercatat terjadi pada balita. Hal ini dibuktikan dengan adanya data dari World Health Organization (WHO) yang menunjukkan angka kematian pada balita di dunia pada tahun 2013 sebesar 45,6 per 1.000 kelahiran hidup dan $15 \%$ diantaranya disebabkan oleh ISPA (Kemenkes RI, 2014).

Di provinsi Papua sendiri terdapat $11.0 \%$ kasus ISPA, berdasarkan hasil Riskesdas pada tahun 2013 2018 kasus ISPA di Provinsi Papua mulai turun dari 47\% kasus menjadi $15 \%$ kasus pada tahun 2018 per 300.000 jiwa dan Papua menempati urutan pertama ISPA dengan jenis terbanyak adalah pneumonia sebanyak $3,7 \%$ serta TB paru sebanyak $0,8 \%$ per100.000 jiwa (Kemenkes RI, 2018).

ISPA merupakan penyebab utama morbiditas dan mortalitas penyakit menular di dunia, hampir empat juta orang meningggal setiap tahunnya, tercatat 98\% disebabkan oleh infeksi saluran pernapasan bawah. Selain itu, tingkat mortalitas sangat tinggi pada bayi, anak-anak, dan orang lanjut usia, terutama di negara-negara berkembang. ISPA merupakan penyakit utama dimana banyak masyarakat melakukan upaya konsultasi atau health search dan rawat inap diberbagai fasilitas pelayanan kesehatan terutama pada bagian perawatan anak (Syahidi dkk, 2016).

Hartono \& Rahmawati (2012) menyebutkan bahwa infeksi pernapasan meningkat pada usia

balita. Pada usia 3-6 bulan merupakan saat- saat hilangnya antibodi dari ibu dan produksi antibodi bayi itu sendiri. Sisa infeksi dari virus berkelanjutan pada waktu balita dan pra sekolah.

Berbagai upaya telah dilakukan oleh pemerintah untuk mengendalikan penyakit ISPA, dimulai sejak tahun 1984 bersamaan dengan diawalinya pengendalian ISPA di tingkat global oleh WHO, namun hingga saat ini upaya tersebut belum memperlihatkan hasil yang signifikan, hal ini terlihat dari banyaknya kasus ISPA yang ditemukan dipelayanan kesehatan baik ditingkat Puskesmas atau Rumah Sakit (Kemenkes, 2013).

ISPA sering berada pada daftar 10 penyakit terbanyak di rumah sakit. Episode penyakit batuk, pilek pada balita di Indonesia diperkirakan 3-6 kali pertahun, artinya seorang individu terutama balita dan anak-anak rata-rata mendapat serangan batuk, pilek sebanyak 3-6 kali setahun (Kunoli, 2013).

Salah satu upaya perawat di rumah sakit adalah dengan melakukan pendidikan kesehatan. Pendidikan kesehatan dapat berperan untuk merubah perilaku individu, kelompok dan masyarakat sesuai dengan nilai-nilai kesehatan. Perubahan perilaku yang diharapkan adalah dapat memelihara dan meningkatkan kesehatan, mencegah risiko terjadinya sakit, melindungi diri dari ancaman penyakit, serta berpartisipasi aktif dalam gerakan kesehatan masyarakat sehingga perubahan perilaku merupakan hasil dari pendidikan kesehatan (Notoatmodjo, 2012).

Keluarga merupakan kelompok terkecil yang memiliki tanggung jawab dan peranan penting dalam melakukan upaya peningkatan kesehatan, pencegahan, serta perawatan pada 
penyakit yang dialami oleh anggota keluarga lainnya, hal ini dikarenakan anggota keluarga yang sakit membutuhkan bantuan dalam mengembalikan stamina agar kembali pulih dan dapat memenuhi kebutuhannya sendiri (Friedman, 2010).

Berdasarkan pengambilan data awal yang peneliti lakukan pada tanggal 29 Mei 2019 diketahui bahwa terdapat sepuluh besar penyakit di ruang IGD diantaranya ISPA, malaria, GEA, asma,

hipertensi, TB paru, ISK, CKD, DM, dan B20 (PLWHA). ISPA menjadi penyakit peringkat pertama di Ruang IGD, angka kejadian penyakit ISPA pada tahun 2018 mencapai 5.334 kasus dengan jenis ISPA terbanyak diantaranya: rinofaringitis akut sebanyak 2.391 kasus, faringitis akut sebanyak 583 kasus, tonsilofaringitis sebanyak 753 kasus, asma bronchiale sebanyak 897 kasus, otitis media akut sebanyak 27 kasus, bronchiopneumonia sebanyak 60 kasus, dan TB paru sebanyak 623 kasus.

Banyaknya kasus ISPA tahun 2018 lebih sering terjadi pada anak-anak dengan rentang usia anak 1-18 tahun sebanyak 2.795 kasus, dewasa >

18 tahun sebanyak 2.303 kasus, dan bayi 0-12 bulan sebanyak 236 kasus. Dari observasi dan pemberi intervensi keperawatan di ruang IGD biasanya pada saat mendapatkan kasus ISPA disetai dengan sesak, pasien akan dianamnesa dan ditentukan diagnosisnya berdasarkan hasil laboratorium, sedangkan intervensi yang biasanya dilakukan oleh perawat seperti: pemasangan nebulizer, pemberian oksigenasi, dan rawat inap.

Berdasarkan wawancara dengan dua belas keluarga pasien ISPA, lima keluarga mengatakan tidak tahu tentang penyakit ISPA, dua keluarga mengatakan tidak tahu mengenai tanda gejala ISPA, dua keluarga mengatakan jika anaknya mengalami batuk bagi mereka itu hal yang biasa cukup menggunakan obat warung dan tiga keluarga mengatakan tidak mengetahui bagaimana mencegah serta perawatan ISPA di rumah.

Berdasarkan pengalaman peneliti sebagai seorang perawat di ruang IGD, pasien-pasien ISPA menyebabkan beban kerja perawat di IGD semakin meningkat hal ini terjadi karena keluarga pasien tidak mengetahui tentang sistem rujukan, dimana jika ada keluarga yang sakit seharusnya dibawa ke Puskesmas terlebih dahulu, lalu ke Rumah Sakit tipe C dan selanjutnya ke Rumah Sakit tipe B. Selain itu, keluarga juga tidak mengetahui cara membagi kategori penyakit kedalam kelompok gawat, darurat, dan gawat darurat, sehingga ruang IGD menjadi penuh.

Berdasarkan uraian tersebut peneliti tertarik untuk melakukan penelitian tentang pengaruh pendidikan kesehatan tentang penyakit infeksi saluran napas akut (ISPA) terhadap pengetahuan keluarga di Ruang IGD RSUD Jayapura.

\section{METODE PENELITIAN}

Jenis penelitian ini menggunakan metode Quasi Eksperimen One Group Pre Test-Post Test. Penelitian ini dilaksanakan pada bulan Agustus hingga Oktober 2019. Pengambilan sampel menggunakan teknik purposive sampling dengan jumlah minimal sampel 30 responden sesuai kriteria inklusi dan eksklusi.

Terdapat 2 instrumen yang digunakan dalam penelitian diantaranya: kuesioner karakteristik responden, dan kuesioner pengetahuan keluarga tentang ISPA. Analisa univariat menggunakan persentase, sedangkan analisa bivariat menggunakan uji analisis Wilcoxon Test.

\section{HASIL PENELITIAN}

\section{Univariat}

Analisa univariat dalam penelitian ini memaparkan mengenai karakteristik responden (usia, pendidikan, pekerjaan), tingkat pengetahuan sebelum dan setelah dilakukan pendidikan kesehatan tentang ISPA.

Tabel 1 Karakteristik Responden

\begin{tabular}{lcc}
\hline Karakteristik & Frekuensi & \% \\
\hline Usia & & \\
17-25 tahun & 8 & 26.7 \\
26-35 tahun & 13 & 43.3 \\
$36-45$ tahun & 5 & 16.7 \\
$46-55$ tahun & 3 & 10.0 \\
56-65 tahun & 1 & 3.3 \\
Total & 30 & 100.0 \\
\hline Pendidikan & & \\
SD & 1 & 3.3 \\
SMP & 6 & 20.0 \\
SMA & 18 & 60.0 \\
Diploma & 3 & 10.0 \\
S1 & 2 & 6.7 \\
Total & 30 & 100.0 \\
\hline Pekerjaan & & \\
Bekerja & 14 & 46.7 \\
Tidak Bekerja & 16 & 53.3 \\
Total & 30 & 100.0 \\
\hline
\end{tabular}

Berdasarkan tabel di atas peneliti menjabarkan usia responden menurut Departemen Kesehatan tahun 2009. Dari 30 respoden yang diteliti, 8 
orang atau $26.7 \%$

berusia 17-25 tahun, 13 orang atau $43.3 \%$ berusia 26-35 tahun, 5 orang atau $16.7 \%$ berusia 36-45 tahun, 3 orang atau $10.0 \%$ berusia 46-55 tahun dan 1 orang atau $3.3 \%$ berusia 56-65 tahun. Hal ini menunjukkan bahwa sebagian besar responden berusia antara 26-35 tahun dan paling sedikit berada pada usia 56-65 tahun.

Pada tabel 1 peneliti menjabarkan tentang karakteristik responden berdasarkan tingkat pendidikan. Dari 30 responden yang diteliti, 1 orang atau $3.3 \%$ berpendidikan SD, 6

orang atau $20.0 \%$ berpendidikan SMP, 18 orang atau $60.0 \%$ berpendidikan SMA, 3 orang atau $10.0 \%$ berpendidikan Diploma dan 2 orang atau $6.7 \%$ berpendidikan S1. Hal ini menunjukkan bahwa sebagian responden berpendidikan SMA dan sangat kecilresponden berpendidikan SD.

Pada tabel 1 peneliti menjabarkan tentang karakteristik responden berdasarkan pekerjaan. Dari 30 responden yang diteliti terdapat 14 orang atau $46.7 \%$ bekerja dan 16 orang atau $53.3 \%$ tidak bekerja. Hal ini menunjukkan bahwa sebagian besar respondentidak bekerja.

Tabel 2 Tingkat Pengetahuan Sebelum Dilakukan Pendidikan Kesehatan

\begin{tabular}{lcc}
\hline Karakteristik & Frekuensi & \% \\
\hline Tingkat Pengetahuan & & \\
Baik & 15 & 50.0 \\
Cukup & 6 & 20.0 \\
Kurang & 9 & 30.0 \\
Total & 30 & 100.0 \\
\hline
\end{tabular}

Pada tabel 2 peneliti menggambarkan tingkat pengetahuan responden sebelum dilakukan pendidikan kesehatan. Diketahui dari 30 responden yang diteliti 15 orang atau $50.0 \%$ memiliki pengetahuan baik, 6 orang atau $20.0 \%$ memiliki pengetahuan cukup dan 9 orang atau $30.0 \%$ memiliki pengetahuan kurang. Hal ini menunjukkan bahwa sebagian keluarga sebelum dilakukan pendidikan kesehatan memiliki pengetahuan baik tentang ISPA.

Tabel 3 Tingkat Pengetahuan Setelah Dilakukan Pendidikan Kesehatan

\begin{tabular}{lcc}
\hline Karakteristik & Frekuensi & \% \\
\hline Tingkat Pengetahuan & & \\
Baik & 30 & 100.0 \\
Total & 30 & 100.0
\end{tabular}

Pada tabel 3 peneliti menggambarkan tingkat pengetahuan responden setelah dilakukan pendidikan kesehatan. Diketahui dari 30 responden yang diteliti, 30 orang atau $100.0 \%$ memiliki pengetahuan baik. Hal ini menunjukkan bahwa seluruh keluarga setelah dilakukan pendidikan kesehatan memiliki pengetahuan baik tentang ISPA.

\section{Bivariat}

Analisa bivariat dalam penelitian ini menggunakan uji Wilcoxon Test untuk mengetahui pengaruh pendidikan kesehatan tentang ISPA terhadap pengetahuan keluarga di Ruang IGD RSUD Jayapura.

Tabel 4 Pengaruh Pendidikan Kesehatan Tentang ISPA

\begin{tabular}{|c|c|c|c|}
\hline Variabel & $\begin{array}{l}\text { Mean } \\
\text { Rank }\end{array}$ & Nilai $Z$ & $\rho$ \\
\hline $\begin{array}{l}\text { Setelah PenKes - } \\
\text { Sebelum Penkes }\end{array}$ & $\begin{array}{l}8.00 \\
0.00\end{array}$ & -3.520 & 0.000 \\
\hline
\end{tabular}

Berdasarkan tabel 4 diketahui hasil uji Wilcoxon Test didapatkan $\rho=0.000$ dengan nilai Z sebelum pendidikan kesehatan - setelah pendidikan kesehatan -3.520 serta mean ranks 8.00. Hasil ini menunjukan bahwa terdapat pengaruh pendidikan kesehatan tentang ISPA yang dilakukan terlihat pada nilai $\rho=0.000<$ 0.05 , dengan nilai negatif -3.520 yang menunjukan adanya pengaruh pengetahuan antara sebelum dan setelah pendidikan kesehatan terhadap keluarga dengan peningkatan rata-rata pengetahuan 8.00.

\section{PEMBAHASAN}

\section{Karakteristik Responden}

a. Berdasarkan Usia

Berdasarkan tabel 1 sebagian besar responden berada pada rentang usia 2635 tahun yaitu sebanyak 13 orang (43.3\%). Hal ini sesuai dengan batasan umur dari Departemen Kesehatan RI (2009) yang menyatakan bahwa umur 26-35 dikategorikan sebagai dewasa awal. Menurut Notoatmodjo (2014) usia adalah umur individu yang terhitung mulai saat dilahirkan sampai berulang tahun, semakin cukup umur, tingkat kematangan dan kekuatan seseorang akan lebih matang dalam berfikir dan 
bekerja.

Dewasa awal merupakan masa transisi dimana terjadi peralihan baik secara fisik, intelektual serta peran sosial, perkembangan sosial masa dewasa awal adalah puncak dari perkembangan sosial masa dewasa. Masa dewas awal juga merupakan masa beralihnya pandangan egosentris menjadi sikap yang empati (Santrock, 2014).

Didukung oleh penelitian Utari., dkk (2014) dimana mayoritas umur responden dalam rentang dewasa awal (18-30 tahun) yaitu sebanyak 19 orang $(63,3 \%)$ diberikan perlakukan penyuluhan ISPA. Usia dewasa merupakan masa dimana seseorang dianggap telah matur, baik secara fisiologis, psikologis, dan kognitif, sehingga usia 18-30 tahun (dewasa awal) merupakan usia yang tepat dalam menganalisa, menerima sesuatu informasi dan kebiasaan berpikir rasional meningkat pada usia dewasa awal (Potter \& Perry, 2012).

Hal ini didukung oleh pendapat Notoatmodjo (2014) bahwa usia seseorang mempengaruhi kemampuan seseorang untuk menerima informasi dan pola pikir seseorang terhadap informasi yang diberikan. Semakin bertambahnya usia maka kemampuan menerima informasi dan pola pikir seseorang semakin berkembang. Kemampuan seseorang untuk menerima informasi yang diberikan kepadanya berhubungan dengan maturitas dari fungsi tubuh baik indera maupun otak dan kesehatan seseorang.

b. Berdasarkan Pendidikan

\section{Berdasarkan hasil penelitian pada tabel}

1 sebagian besar responden memiliki status pendidikan SMA yaitu sebanyak 18 orang (60.0\%). Pendidikan memiliki peranan yang sangat penting dalam menentukan kualitas manusia, dengan pendidikan manusia memperoleh pengetahuan dan informasi. Semakin tinggi tingkat pendidikan seseorang maka akan semakin berkualitas hidupnya (Hurlock, 2012).

Didukung oleh penelitian yang dilakukan oleh Fatmawati (2017) yang berjudul pengaruh pendidikan kesehatan dengan media leaflet diketahui bahwa dari 20 responden 12 (60.0\%) orang yang diteliti sebagian besar berada pada tingkat pendidikan SMA.

Menurut Notoatmodjo (2012) tingkat pendidikan dapat berpengaruh pada seseorang, dimana tingkat pendidikan akan menentukan mudah atau tidaknya orang tersebut dalam menyerap dan memahami pengetahuan yang mereka peroleh, umumnya semakin tinggi pendidikan seseorang makin baik pula pengetahuannya. Seseorang dengan pendidikan yang baik, lebih matang terhadap proses perubahan pada dirinya, sehingga lebih mudah menerima pengaruh dari luar yang positif, obyektif dan terbuka terhadap berbagai informasi termasuk informasi kesehatan.

\section{c. Berdasarkan Pekerjaan}

Berdasarkan pekerjaan, dari hasil penelitian diketahui bahwa lebih dari sebagian responden tidak bekerja sebanyak 16 orang $(53.3 \%)$, hal ini terjadi karena responden adalah keluarga pasien ISPA dimana yang membawa pasien mayoritas adalah ibu atau Istri Didukung oleh penelitian yang dilakukan oleh Fatmawati (2017) dimana dari 20 responden 15 (75.0\%) ibu yang diteliti sebagian besar tidak bekerja. Peneliti juga lebih banyak bertemu dengan istri daripada suami karena istri sering berada di rumah dan bekerja sebagai ibu rumah tangga.

Menurut Friedman., dkk (2010). Istri dipandang sebagai pengurus rumah tangga dan berperan sebagai perawat anak, pemimpin kesehatan keluarga, sahabat atau teman bermain anak. Ibu rumah tangga berperan untuk mengurus rumah tangga, sebagai pengasuh dan pendidik anak-anaknya, pelindung dan salah satu kelompok sosial serta sebagai anggota masyarakat dan lingkungan (Efendi, 2009).

Menurut peneliti jika ditinjau dari jenis pekerjaan yang sering berinteraksi dengan orang lain lebih banyak terpapar informasi atau pengetahuan bila dibandingkan dengan orang tanpa ada interaksi dengan orang lain. Seorang ibu rumah tangga lebih sering berinteraksi dengan keluarga dan banyak menghabiskan waktu di rumah dan hanya saatsaat tertentu para ibu rumah tangga bisa berinteraksi dengan orang banyak seperti saat arisan keluarga, pengajian atau ibadahibadah, dimana seharusnya banyak terpapar informasi dengan berbagi pengalaman kepada ibu rumah tangga yang lainnya tentang masalah kesehatan. Walaupun berada di rumah ibu rumah tangga bisa aktif mencari tahu 
tentang informasi kesehatan yang bisa didapat melalui internet, televisi ataupun koran/ majalah yang dapat meningkatakan pengetahuan untuk dapat mencegah penyakit, memelihara kesehatan dan dapat meningkatkan status kesehatan keluarga.

\section{Pengaruh Pendidikan Kesehatan tentang ISPA terhadap Pengetahuan Keluarga}

Berdasarkan hasil penelitian pada tabel 4 diketahui $\rho=0.000$ yang berarti ada pengaruh antara pendidikan kesehatan tentang ISPA terhadap pengetahuan keluarga. Hal ini terlihat dari peningkatan yang signifikan pada tingkat pengetahuan sebelum dilakukan pendidikan kesehatan tentang ISPA, dimana sebagian keluarga memiliki pengetahuan baik 15 orang (50.0\%), sedangkan setelah dilakukan pendidikan kesehatan tentang ISPA terjadi peningkatan pada seluruh keluarga menjadi baik 30 orang (100.0\%).

Pengetahuan merupakan hasil tahu yang diperoleh melalui penglihatan ataupun pendengaran dan juga pengetahuan dipengaruhi oleh pendidikan (Wawan \& Dewi, 2011). Ada beberapa faktor yang yang mempengaruhi pengetahuan yaitu faktor umur, pengalaman, pekerjaan, lingkungan, sosial budaya, informasi dan pendidikan (Notoadmodjo, 2012).

Seseorang bisa memiliki pengetahuan tinggi jika memiliki pengetahuan yang baik serta didukung pengalaman-pengalaman dalam mengikuti kegiatan penyuluhan kesehatan seperti pendidikan kesehatan atau promosi kesehatan (Notoatmodjo, 2012). Menurut Effendy (2012) tujuan dari pemberian pendidikan kesehatan adalah agar tercapainya perubahan perilaku individu, keluarga, dan masyarakat dalam membina dan memelihara perilaku sehat dan lingkungan sehat, serta berperan aktif dalam upaya mewujudkan derajat kesehatan yang optimal.

Pada saat peneliti melakukan pendidikan kesehatan, peneliti menggunakan metode ceramah yang disertai dengan media leaflet. Peneliti menyampaikan ceramah dengan baik sehingga mampu dimengerti oleh keluarga. Peneliti memilih metode ceramah karena lebih mudah disampaikan serta mampu dipahami dengan baik, adanya komunikasi dua arah membuat keluarga lebih memahami informasi mengenai ISPA yang disampaikan oleh peneliti sehingga dapat mempengaruhi tingkat pengetahuan pasien.

Pemilihan media presentasi yang disajikan berupa teks, gambar serta animasi yang dikombinasikan, mampu menarik perhatian seseorang dalam melaksanakan pendidikan kesehatan sehingga dapat meningkatkan pengetahuan responden (Daryanto, 2013). Hal ini didukung oleh penelitian Novrianda., dkk (2015) yang melakukan pendidikan kesehatan dengan menggunakan media booklet, penggunaan booklet yang memiliki kombinasi antara teks dan gambar membuat responden menjadi lebih paham tentang informasi mengenai penyakitISPA.

Berdasarkan hasil penelitian yang dilakukan oleh Utari., dkk (2014) terjadi peningkatan pengetahuan keluarga pada kelompok yang diberikan pendidikan kesehatan dengan menggunakan media audiovisual $\rho=0,001<\alpha=0,05$ oleh karena itu pemilihan dan penggunaan media merupakan salah satu komponen yang penting. Pendidikan kesehatan merupakan proses perubahan perilaku individu secara dinamis, dimana perubahan tersebut bukan sekedar proses transfer pengetahuan dari seseorang ke orang lain, tetapi perubahan terjadi karena adanya kesadaran diri individu, kelompok atau masyarakat untuk mempelajarinya (Mubarak \& Chayatin, 2012).

Dalam melakukan pendidikan kesehatan tentang ISPA, peneliti menjelaskan secara singkat dan jelas mengenai pengertian, penyebab, tanda gejala, jenis, penatalaksanaan dan perawatan, serta pencegahan ISPA. berdasarkan pengalaman peneliti tindakan keperawatan untuk pasien ISPA diantaranya memberikan rasa nyaman dengan melakukan kolaborasi pemberian oksigen atau melakukan nebulisasi, ditambah dengan peraturan tambahan dimana Papua sebagai daerah epidemik TBC (Tuberculosis) maka akan dilakukan pemeriksaan laboratorium.

Terdapat beberapa faktor yang mempengaruhi kejadian penyakit ISPA diantaranya faktor anak, faktor lingkungan dan faktor ibu/ keluarga. Faktor anak terdiri dari umur, status gizi, jenis kelamin, status imunisasi campak, pemberian vitamin A dan pemberian ASI. Faktor lingkungan terdiri dari kepadatan hunian, pencemaran udara dalam 
rumah. Sedangkan faktor ibu/ keluarga meliputi pendidikan dan pengetahuan(Novrianda., dkk, 2015).

Dari hasil penelitian sebelum dilakukan pendidikan kesehatan diketahui terdapat 15 responden $(50.0 \%)$ memiliki kriteria pengetahuan baik, 6 responden $(20.0 \%)$ berpengetahuan cukup, dan 9 responden $(30.0 \%)$ berpengetahuan kurang, sedangkan setelah dilakukan pendidikan kesehatan seluruh pengetahuan responden meningkat menjadi baik (100.0\%). Didukung oleh penelitian Yusyaf (2011) yang menunjukkan bahwa adanya peningkatan pengetahuan keluarga setelah diberikan pendidikan kesehatan dengan media lembar balik pada kelompok eksperimen. Media audiovisual memberikan rangsangan melalui mata dan telinga. Media audiovisual yang menarik dapat menarik perhatian individu dan pesan yang disampaikan menjadi lebih mudah untuk dipahami.

Menurut Mubarak \& Chayatin (2012) dalam memberikan pendidikan kesehatan agar dapat mencapai tujuan harus memperhatikan beberapa hal diantaranya yaitu materi atau pesan dan metode yang disampaikan menggunakan bahasa yang mudah dimengerti oleh masyarakat dalam bahasa kesehariannya, materi tidak terlalu sulit dan dimengerti oleh sasaran. Penyampaian materi sebaiknya menggunakan alat peraga agar menarik perhatian sasaran, materi atau pesan disampaikan merupakan kebutuhan dasar dalam masalah kesehatan dan keperawatan yang dihadapi sasaran. Penyebarluasan informasi dengan menggunakan media visual seperti booklet, poster, lembar balik dalam penelitian dan pendidikan kesehatan telah banyak dilakukan dan menunjukkan adanya peningkatan pengetahuan. Oleh sebab itu, meningkatnya pengetahuan responden tidak saja diperlukan media yang menarik melainkan juga kemampuan dari perawat sebagai pemberi informasi agar lebih mudah dipahami. Dalam penelitian ini, peneliti melakukan kombinasi dari kemampuan komunikasi terapeutik dalam melakukan penyampaian dan menggunakan media leaflet yang dipadukan dengan berbagai gambar guna meningkatkan rasa ingin tahu serta menarik perhatian keluarga agar lebih ingin tahu tentang penyakit ISPA.

\section{KESIMPULAN}

Berdasarkan hasil dan pembahasan tentang pengaruh pendidikan kesehatan tentang infeksi saluran napas akut (ISPA) terhadap pengetahuan keluarga di Ruang IGD RSUD Jayapura, maka dapat disimpulkan:

1. Dari hasil penelitian diketahui tingkat pengetahuan keluarga sebelum diberikan pendidikan kesehatan tentang ISPA dengan kriteria baik 15 orang $(50.0 \%)$, cukup 6 orang $(20.0 \%)$, dan kurang 9 orang $(30.0 \%)$.

2. Dari hasil penelitian diketahui tingkat pengetahuan keluarga setelah diberikan pendidikan kesehatan tentang ISPA dengan kriteria baik 30 orang (100.0\%).

3. Dari hasil penelitian diketahui ada pengaruh pendidikan kesehatan tentang infeksi saluran napas akut (ISPA) terhadap pengetahuan keluarga di Ruang IGD RSUD Jayapura, hal ini ditunjukkan dari hasil uji Wilcoxon $\rho$ (Asymp. Sig. 2tailed $)=0.000<0.05$.

\section{DAFTAR PUSTAKA}

Daryanto. (2013). Inovasi

Pembelajaran Efektif.

Bandung: Yrma Widya.

Depkes RI. (2009). Profil Kesehatan

Indonesia.

Jakarta

Dinas Kesehatan Malang. (2015). Profil Dinas Kesehatan 2015. Jakarta: Departemen Kesehatan Republik Indonesia.

Efendi, M. A. (2009). The Power Of Corporate Governance: Teori dan Implementasi. Jakarta: Salemba Empat.

Effendy, N. (2012). Dasar-dasar Keperawatan Kesehatan Masyarakat (Ed. 2). Jakarta: EGC.

Fatmawati, T. Y. (2017). Pengaruh pendidikan kesehatan dengan media leaflet terhadap pengetahuan ibu tentang penatalaksanaan ISPA pada balita di Posyandu. Jurnal Ilmiah Universitas Batanghari Jambi, vol.17. no.3.

Friedman, M. M., Bowden, O., \& Jones, M. (2010). Buku Ajar Keperawatan Keluarga: riset, teori \& praktik. Jakarta: EGC.

Friedman. (2010). Keperawatan Keluarga Teori dan Praktik. Jakarta: EGC.

Hurlock, E. B. (2012). Psikologi Perkembangan, Suatu Pendekatan 
Sepanjang Rentang Kehidupan. Jakarta: Erlangga.

Kemenkes RI. (2013). Pedoman Penatalaksaan Klinis Infeksi Saluran Pernapasan Akut Berat. Diakses dari http://www.depkes.go.id /resources/download/puskes-haji/4-pedoman -tatalaksana-klinis-ispa-berat-suspek-merscov.pdf.

Kemenkes RI. (2014). Profil Kesehatan Indonesia Tahun 2013. Jakarta: Kementerian Kesehatan.

Kemenkes RI. (2018). Hasil Utama Rikesdas 2018. BalitbangKes.

Kunoli, F. J. (2013). Pengantar Epidemiologi Penyakit Menular. Jakarta: Trans Info Media

Mubarak, W. I., \& Chayatin, N. (2012). Ilmu Keperawatan Komunitas Pengantar dan Teori. Jakarta: Salemba Medika.

Notoatmodjo, S. (2012). Promosi kesehatan dan Perilaku Kesehatan. Jakarta:Rineka Cipta.

Notoatmodjo, S. (2014). Ilmu Perilaku Kesehatan. Jakarta: Rineka Cipta.

Novrianda, D., Lucida, H., \& Soumariris, I. (2015). Perbandingan efektivitas pendidikan kesehatan terhadap pengetahuan dan kemampuan ibu merawat balita ispa di Puskesmas
Padang Pasir Dan Pauh. Jurnal Sains Farmasi \& Klinis, vol. 01 No. 02.

POM. (2011). Infeksi Saluran Pernapasan.Diakses dari http://www.pom.go.id/pom/publikasi/ artikel/artikel02.html.

Potter, P. A., \& Perry, A.G. (2012).

Fundamental of Nursing. Jakarta:

EGC. Santrock, J. W. (2014). Psikologi

Pendidikan.

Jakarta. Selemba Humanika

Utari, W., Arneliwati., \& Novayelinda, R. (2014). Efektifitas pendidikan kesehatan terhadap peningkatan pengetahuan keluarga tentang infeksi saluran napas akut (ISPA). Open Journal Sistem. Diakses dari https://media.neliti.com/media/publ icati ons/189248-ID-efektifitaspendidikan -kesehatan-terhada.pdf.

Wawan, A., \& Dewi M. (2011). Teori dan Pengukuran Pengetahuan, Sikap, dan Perilaku Manusia. Cetakan II. Yogyakarta: Nuha Medika. Yusyaf, S. R. (2013). Efektifitas Pendidikan Kesehatan Menggunakan Metode Pendidikan Individual Terhadap Peningkatan Pengetahuan Keluarga Tentang Demam Berdarah Dengue. (Skripsi Tidak dipublikasikan). Program Studi Ilmu Keperawatan Universitas Riau. 